\title{
Visual Eyes: A Quantitative Analysis of the Photoreceptor Layer in Deep-Sea Sharks
}

\author{
Amy S. Newman ${ }^{a}$ Justin N. Marshall ${ }^{b}$ Shaun P. Collin ${ }^{a}$ \\ ${ }^{a}$ Neuroecology Group, School of Animal Biology and the UWA Oceans Institute, The University of Western Australia,

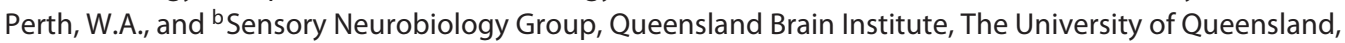 \\ St. Lucia, Qld., Australia
}

\section{Key Words}

Photoreceptor · Sharks · Stereology · Retinal topography ·

Retinal wholemount

\begin{abstract}
The marine environment presents unique visual challenges for a range of organisms, particularly those dwelling at great depths, where sunlight may either be absent or drop to very low levels. Under these environmental conditions, the visual system must maximise light absorption in order to enhance the detection of prey, predators and potential mates. Using stereological analysis of retinal wholemounts, the distribution and number of photoreceptors (rods) was determined for 5 deep-sea shark species from a range of depths (46$1,500 \mathrm{~m}$ ). All species possessed areas of increased photoreceptor density (with peaks between 41,000 and 82,000 rods/ $\mathrm{mm}^{2}$ ) within discrete regions of the retina. The total number of rods in the photoreceptor layer also varied between $17 \times$ $10^{6}$ and $63 \times 10^{6}$. It is evident that increasing sensitivity of the retina is an important adaptation to life in the deep sea. The location of discrete areas of high cell density within the photoreceptor layer of the retina corresponds to discrete areas of the visual field that are sampled at a higher intensity, hence increasing sensitivity. The location of these areas of
\end{abstract}

increased sensitivity differed between the species of this study. The disparity of areas of increased sensitivity seen between species is thought to reflect distinctive predator avoidance and prey capture strategies. This study reveals that the visual demands of deep-sea sharks vary interspecifically and that sampling of each species' visual field is not solely determined by its habitat.

(C) 2013 S. Karger AG, Basel

\section{Introduction}

The open ocean presents many visual challenges for marine organisms, particularly those dwelling at great depths. In some environments, such as the north-western Mediterranean Sea, $99 \%$ of natural light is absorbed within the first $150 \mathrm{~m}$ [Ivanoff, 1975]. In contrast, in the clear oceanic waters of the western and central North Atlantic Oceans, photometers sensitive to light intensities as low as $10^{-15} \mu \mathrm{W} / \mathrm{cm}^{2}$ have detected the noon sunlight at depths greater than $900 \mathrm{~m}$ [Clarke and Kelly, 1965]. It is thought that fish living at depths of up to $1,000 \mathrm{~m}$ in clear water environments can distinguish day and night from down-welling surface light [Clarke and Denton, 1962]. However, beyond $1,000 \mathrm{~m}$ there is no natural light avail-

\section{KARGER}

E-Mail karger@karger.com

www.karger.com/bbe
(C) 2013 S. Karger AG, Basel

0006-8977/13/0824-0237\$38.00/0
Amy Newman

School of Animal Biology (M317), The University of Western Australia

35 Stirling Hwy, Crawley

Perth, WA 6009 (Australia)

E-Mail ams.newman@gmail.com 
able for vision or for maintaining circadian rhythms by photoentrainment [McFarland, 1986].

The scarcity of available light at depth means that visual adaptations that serve to enhance light detection are a necessity. On a macro scale, such adaptations may be an increase in relative eye size [Lisney and Collin, 2007], a large and immobile pupillary aperture [Crescitelli, 1991; Bozzano, 2004] and the presence of a mirror-like structure located at the back of the eye, known as a tapetum lucidum [Braekevelt, 1986]. The tapetum, located behind the retina, increases sensitivity by reflecting any photons that pass through the photoreceptor layer of the retina 'uncaptured' back through these photoreceptors for a second chance to be absorbed

The type, morphology and spatial arrangement of retinal photoreceptors in all organisms have been under intense selective pressure as each species has adapted to the light environment it encounters and the visual tasks it requires for survival [Lythgoe, 1968, 1980; Guthrie and Muntz, 1993]. Sharks are no exception and studies of the morphology of photoreceptors have revealed that the majority of species possess a duplex retina containing both rod and cone photoreceptors [Kato, 1962; Stell, 1972; Stell and Witkovsky, 1973; Gruber et al., 1975; Gruber and Cohen, 1985; Kohbara et al., 1987; Sillman et al., 1996; Schieber et al., 2012], with the exception of some deepdwelling species whose retinae appear to have lost their cones and contain only morphologically rod-like receptor cells [Kohbara et al., 1987; Bozzano et al., 2001; Bozzano, 2004]. Among the species possessing a duplex retina, the ratio of cones to rods is highly variable, ranging from 1:4 in the great white shark, Carcharodon carcharias [Gruber et al., 1975], to 1:100 in the deeper dwelling smooth dogfish, Mustelus canis [Stell and Witkovsky, 1973]; however, it is important to note that the ratio of photoreceptors is by no means spatially consistent across the photoreceptor layer.

Variability within the photoreceptor layer in vertebrates occurs with respect not only to the subtypes present but also to receptor size. An increase in visual sensitivity can be achieved by enlarging the portion of the photoreceptor responsible for photon absorption, i.e. the outer segment [Fritsches et al., 2003]. The outer segment length of rod photoreceptors, a photoreceptor type present in all shark retinae described thus far, has been reported to range from $16 \mu \mathrm{m}$ in the lemon shark, Negaprion brevirostris [Gruber, 1963], to $77 \mu \mathrm{m}$ in the blackmouth castshark, Galeus melastromus, a species recorded at depths of up to 1,700 $\mathrm{m}$ [Bozzano et al., 2001]. As with photoreceptor ratios, photoreceptor dimensions are not homogenous across the retina, with an increase in photoreceptor outer segment length often coinciding with the location of areas of topographic retinal specialization [Bozzano et al., 2001].

Topographic analysis of the photoreceptor layer identifies areas of specialization within the retina, where photoreceptor densities are highest. These areas mediate increased sampling of specific regions of the visual field that are important to each species' behaviour and ecology [Hughes, 1977]. These regions of increased cell density within the retina are termed areae and in some species occur within an elongated region of incremental increase in cell density known as a visual streak [Hughes, 1977]. Topographic mapping of photoreceptors has been used to reveal links between visually related ecology and behaviour in many vertebrates, including diurnal and nocturnal primates [Packer et al., 1989; Wikler and Rakic, 1990; Troilo et al., 1993; Wilder et al., 1996; Andrade da Costa and Hokoç, 2000; Hendrickson et al., 2000; Finlay et al., 2008], marsupials [Hemmi and Gruenert, 1999; Arrese et al., 2000, 2003, 2005], and teleosts [Beaudet et al., 1997; Fritsches et al., 2003; Lisney and Hawryshyn, 2010].

In contrast, studies mapping shark photoreceptor topography are limited to just a few species which include the ornate wobbegong, Orectolobus ornatus, the whitetip reef shark, Triaenodon obesus, the epaulette shark, $\mathrm{He}$ miscyllium ocellatum [Litherland and Collin, 2008], the sandbar shark, Carcharhinus plumbeus, and only one deep-dwelling species, the shortspine spurdog, Squalus mitsukurii [Litherland et al., 2009]. Interestingly, each of these shark species examined displays a unique photoreceptor topography pattern and peak density (ranging from 53,000 to 115,300 cells $/ \mathrm{mm}^{2}$ ), reflective of their differing visual demands. For example, several areae located within a dorsal horizontal visual streak are exhibited by the epaulette shark, increasing visual sampling of the lower frontal and lateral regions of the visual field [Litherland and Collin, 2008]. In the sandbar shark, an increase in cell density from the peripheral to the central retina, culminating in one centrally located area centralis rich in cones, allows this species to scan the lateral visual field with improved visual sensitivity [Litherland et al., 2009].

The present study examines the number and topographic arrangement of photoreceptor cells within the retinae of 5 deep-sea shark species. A range of visual specializations is revealed that may reflect differences in the behaviour, visual ecology and visual demands of each species, all of which live at different depths. Currently, little is known about the life history of deep-sea shark species, especially with regard to prey capture, predator 
Table 1. Overview of the 5 species of deep-sea sharks examined, their size, depth range, diet and status

\begin{tabular}{|c|c|c|c|c|c|}
\hline Species & $\begin{array}{l}\text { Projected } \\
\text { size at ma- } \\
\text { turity, cm }\end{array}$ & Projected habitat type & $\begin{array}{l}\text { Projected } \\
\text { depth range, } \\
\mathrm{m}\end{array}$ & Diet & $\begin{array}{l}\text { Conservation } \\
\text { status }\end{array}$ \\
\hline $\begin{array}{l}\text { Longsnout dogfish } \\
\text { D. quadrispinosum }\end{array}$ & $\begin{array}{l}87 / 110 \\
(\mathrm{M} / \mathrm{F})^{\mathrm{b}}\end{array}$ & $\begin{array}{l}\text { outer continental } \\
\text { shelf and slope }\end{array}$ & $150-1,360$ & bony fishes & $\begin{array}{l}\text { IUCN red list: } \\
\text { near threatened }\end{array}$ \\
\hline $\begin{array}{l}\text { Beige catshark } \\
\text { P. bigus }\end{array}$ & $\begin{array}{l}72 \\
(\mathrm{~F})\end{array}$ & $\begin{array}{l}\text { offshore deepwater } \\
\text { plateau }^{\text {b }}\end{array}$ & $590-606$ & unknown & $\begin{array}{l}\text { IUCN red list: } \\
\text { data deficient }\end{array}$ \\
\hline $\begin{array}{l}\text { Mcmillan's catshark } \\
\text { P. macmillani }\end{array}$ & $\begin{array}{l}52 \\
(\mathrm{~F})^{\mathrm{b}}\end{array}$ & Deepwater ${ }^{\mathrm{b}}$ & $670-1,500$ & unknown & $\begin{array}{l}\text { IUCN red list: } \\
\text { data deficient }\end{array}$ \\
\hline
\end{tabular}

Information compiled from fishbase.org, ${ }^{\mathrm{a}}$ Compagno et al. [2005] and ${ }^{\mathrm{b}}$ Last et al. [2010].

IUCN = International Union for Conservation of Nature.

avoidance and mate recognition, due to the inaccessibility of much of the deep-sea and the inherent difficulties in observing their natural behaviour in situ. The species examined in this study were selected as they are either commonly encountered as by-catch on deep-sea fishery vessels or rare species endemic to small geographical areas. Therefore, any predictions that can be made about their life history traits may reduce their vulnerability to the expansion of deep-sea fishing activities [Stevens et al., 2000; Gianni, 2004; Cavanagh and Kyne, 2005].

\section{Materials and Methods}

Source of Animals

Mature individuals from 5 deep-sea shark species were analysed in this study: the Borneo catshark, Apristurus platyrhynchus [Tanaka, 1908] $(\mathrm{n}=3)$, the longsnout dogfish, Deania quadrispinosum [McCulloch, 1915] $(\mathrm{n}=3)$, the prickly dogfish, Oxynotus bruniensis [Ogilby, 1893] $(\mathrm{n}=3)$, the beige catshark, Parmaturus bigus [Séret and Last, 2007] $(\mathrm{n}=3)$, and McMillan's catshark, $P$. macmillani [Hardy, 1985] $(\mathrm{n}=3)$ (table 1; fig. 1). All specimens were donated from commercial fishermen operating along the Norfolk Ridge in New Zealand waters, where these species are encountered as by-catch through deep-sea trawling. Deep-sea individuals were captured in trawls that took place in New Zealand's Exclusive Economic Zone (EEZ) with a maximum net depth ranging from 950 to $1,080 \mathrm{~m}$ during two fishing expeditions (May/June 2009 and June 2011). On board, total length $\left(T_{L}\right)$ was measured to the nearest $0.1 \mathrm{~cm}$ and sex was recorded for each specimen. Both left and right eyes were enucleated from freshly deceased individuals. The cornea, lens and vitreous humor were removed before the eye was immersion fixed for morphological and topographical analyses.

\section{Preparation and Analysis of Retinal Morphology}

Light microscopical examination was carried out on the retina from the right eye of one individual of each species following the methods of Theiss et al. [2007] and Collin [2009]. The excised eyecups were fixed by immersion on-board and stored in 2\% paraformaldehyde and $2.5 \%$ glutaraldehyde in $0.1 \mathrm{M}$ cacodylate buffer $(\mathrm{pH}$ 7.4) for a period of up to 2 years. In the laboratory, the retina and the underlying pigment layer and choroidal tapetum lucidum were carefully dissected away from the sclera. For each species, 4 small pieces of tissue from the centre of the dorsal, ventral, nasal and temporal retina were removed. Retinal pieces were rinsed in saline and $0.15 \mathrm{M}$ phosphate buffer ( $\mathrm{pH} 7.2-7.4$ ) for $15 \mathrm{~min}$ each, before being placed in a $50 \%$ solution of osmium tetroxide in $0.15 \mathrm{M}$ phosphate buffer for $90 \mathrm{~min}$. Retinal tissue was then dehydrated in a graded series of acetones and embedded in Procure/Araldite (ProSciTech Pty. Ltd., Australia). Ten semi-thin sections $(1 \mu \mathrm{m})$ from each piece of retinal tissue were cut on an LKB ultramicrotome using a glass knife, mounted on slides and stained with toluidine blue. Following permanent mounting and cover-slipping in Entellan (ProSciTech), stained retinal sections were photographed using an Olympus digital camera mounted on a Leitz Dialux 20 light microscope.

\section{Wholemount Preparation}

One eye from 3 specimens of each species was used for analysis of photoreceptor topography. Where possible, the right and left eyes from the same specimen were analysed to control for left/right variation and, again, where possible an eye from at least one male and female was included. Following the procedure of Collin [1988] and Coimbra et al. [2006], eyecups were fixed by immersion in $4 \%$ paraformaldehyde in $0.1 \mathrm{M}$ phosphate buffer ( $\mathrm{pH}$ 7.2-7.4) before retinae were carefully removed from the eyecup and teased free 
Fig. 1. Deep-sea shark species. Position of the eye in the head when viewed from above and lateral view of the shark. a Borneo catshark, A. platyrhynchus. b Longsnout dogfish, D. quadrispinosum. c Prickly dogfish, O. bruniensis. d Beige catshark, P. bigus. e McMillan's catshark, P. macmillani. Note the pronounced eye shine from the eyes. Scale bars $=10 \mathrm{~cm}$.

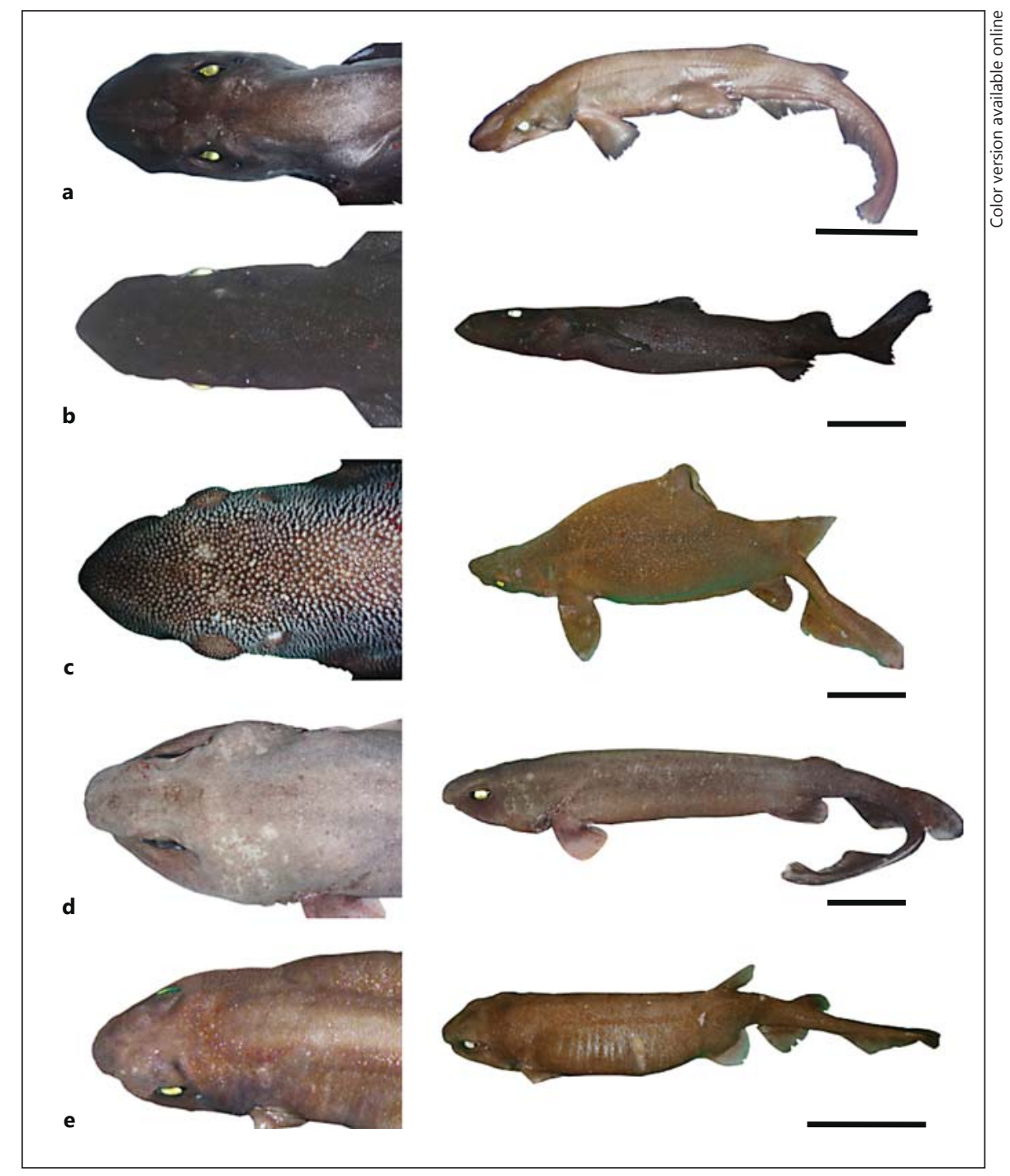

from the underlying retinal pigment epithelial layer and tapetum. A number of slits were made in the peripheral retina to allow the retina to be wholemounted flat on an unsubbed slide [Stone, 1981] (fig. 2a). With the photoreceptor layer uppermost, the flattened and unstained retina was then cover-slipped in glycerol [Curcio et al., 1987] and sealed with nail varnish to prevent dehydration.

\section{Stereological Analysis of Retinal Wholemounts}

The optical fractionator method was employed to estimate the topographic distribution and total number of cells in the photoreceptor layer of the wholemounted retina [Coimbra et al., 2009] using an Optiphot-2 (Nikon, Japan) microscope equipped with a motorized stage (MAC200; Ludi Electronic Products, Hawthorne, N.Y., USA) connected to a computer installed with Stereo Investigator (version 10; MicroBrightField, Colchester, Vt., USA). The optical fractionator method involves systematic random sampling of a subset of cells in unbiased counting frames. These counting frames or sites are located at uniform distances within an unbiased virtual grid overlaying the entire tissue region of interest in order to chart cell density changes and estimate the total cell population. For further details on the optical fractionator method, see West et al. [1991] and Bonthius et al. [2004].

Using the Stereo Investigator software, the photoreceptor layer was outlined by demarcation of the wholemounted retina prior to sampling and for the calculation of the retinal area. The optic nerve head (fig. 2c) was excluded from analysis. As the photoreceptor inner segment radius was reasonably consistent across species, the counting frame dimensions for sampling in all species was defined to be $30 \times 30 \mu \mathrm{m}$ (fig. $2 \mathrm{~b}$ ). Pilot studies showed that a counting frame of this size was adequate to detect any changes in cell density across the retina. All photoreceptors that fell wholly within the counting frame or that intersected the acceptance line without touching the rejection line were included in the sample [Gundersen and Jensen, 1987]. As the size of the eye, and consequently the retina, varied across species, grid size was species specific to achieve an acceptable coefficient of error (CE). This is used to assess the 

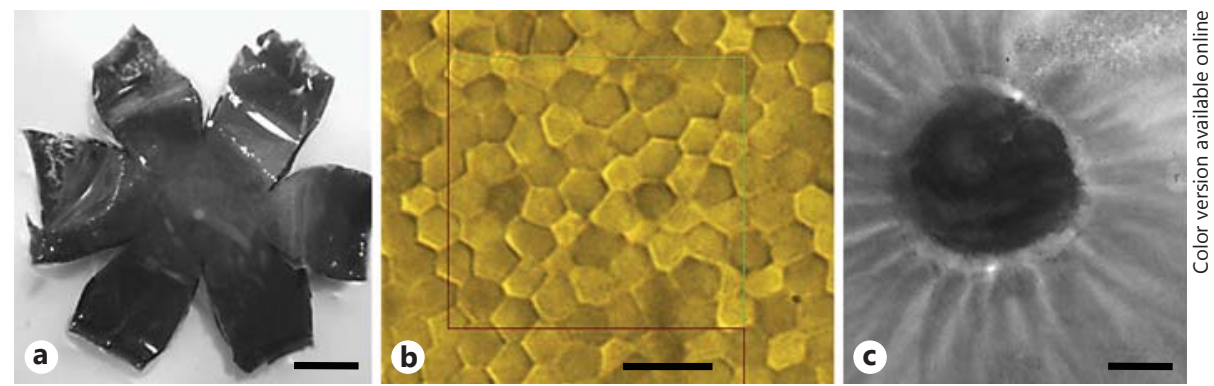

Fig. 2. Topographic mapping of photoreceptor cells. a Scleral eyecup with the retina uppermost, where peripheral slits have been made to allow flattening. The retina is then carefully removed from the sclera, freed of the underlying choroidal tapetum lucidum and wholemounted onto a non-subbed slide. Scale bar $=1 \mathrm{~cm}$. b Screen shot taken from Stereo Investigator showing the green inclusion line and the red exclusion line overlaid on the rod photoreceptor array, viewed here on the axial plane. Colors are visible online only. Scale bar $=10 \mu \mathrm{m}$. c Optic nerve head as seen under a light microscope. Note the fascicles or bundles of ganglion cell axons converging on the optic nerve head. Scale bar $=200 \mu \mathrm{m}$. accuracy of the cell population estimates (table 2). The present study utilized Schaeffer's CE with a value of $<0.1$, which is considered acceptable [Glaser and Wilson, 1998; Slomianka and West, 2005; Fileta et al., 2008].

The total number of photoreceptors in each retinal wholemount is calculated by the optical fractionator using the following equation:

$\mathrm{N}$ total $=\Sigma \mathrm{Q} \times 1 / \mathrm{asf} \times 1 / \mathrm{ssf} \times 1 /$ tsf

where $\Sigma Q$ is the total number of neurons counted, the area sampling fraction (asf) is the ratio of the area of the counting frame to the area of the grid, the section sampling fraction (ssf) is the ratio of the number of sections sampled to the total number of sections and the thickness sampling factor (tsf) is the ratio of the section thickness sampled to the total thickness of the section [West et al., 1991; Bonthius et al., 2004]. As the retinal wholemount is considered one section and the photoreceptor layer contains only one stratum, both the ssf and the tsf are 1 [Coimbra et al., 2009].

For topographic comparison, the number of cells that fell within the counting frame $(30 \times 30 \mu \mathrm{m})$ within each square of the grid was converted into cells per square millimetre. Using the known locations of the counting frame from the overlaid computerized grid, iso-density contours were constructed by interpolation between regions with similar cell densities following the methods of Collin and Pettigrew [1988]. High-resolution subsampling was conducted in the region of peak cell density, using a reduced grid size, to increase the precision of locating the exact peak in each retina. The specimen of each species with the lowest CE was chosen as the representative topographic photoreceptor map presented in this paper.

\section{Results}

All species of deep-sea sharks investigated in the present study share a number of ocular characteristics. They all have well-developed eyes positioned laterally on the head, with the exception of $A$. platyrhynchus whose dor-
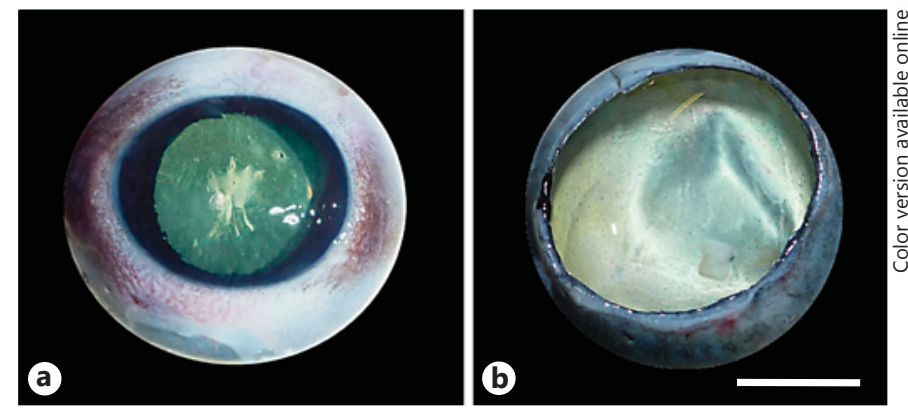

Fig. 3. The eye of deep-sea sharks. a Enucleated eye from the Prickly dogfish, O. bruniensis. b The green/yellow tapetal reflectance of the longsnout dogfish, D. quadrispinosum, eye after the cornea, lens and vitreous humor have been removed. Scale bar $=1 \mathrm{~cm}$.

soventrally flattened snout gives the eyes an almost dorsal location. Each species also possesses a large, round pupil when observed alive in the floodlit conditions of the fishing vessel, and in fresh specimens all species exhibited a strong fundal eye shine indicating the presence of a reflective tapetum lucidum (fig. 1, 3, 4a). Within the retinal fundus, the optic nerve head is located slightly off centre within the naso-ventral retinal quadrant.

\section{General Morphology of the Retina}

Light micrographs of transverse sections revealed that all 5 species possess a tapetum lucidum located within the choroid of the eye (fig. 4a). The tapetal cells are comprised of plates of reflective material (putatively guanine) separated by aggregations of melanocytes. Internal to the tapetal cells is a thick Bruch's membrane, separating the 
Table 2. Data on the specimens and quantitative information about the retina and regions of specialization as estimated by the optical fractionator method

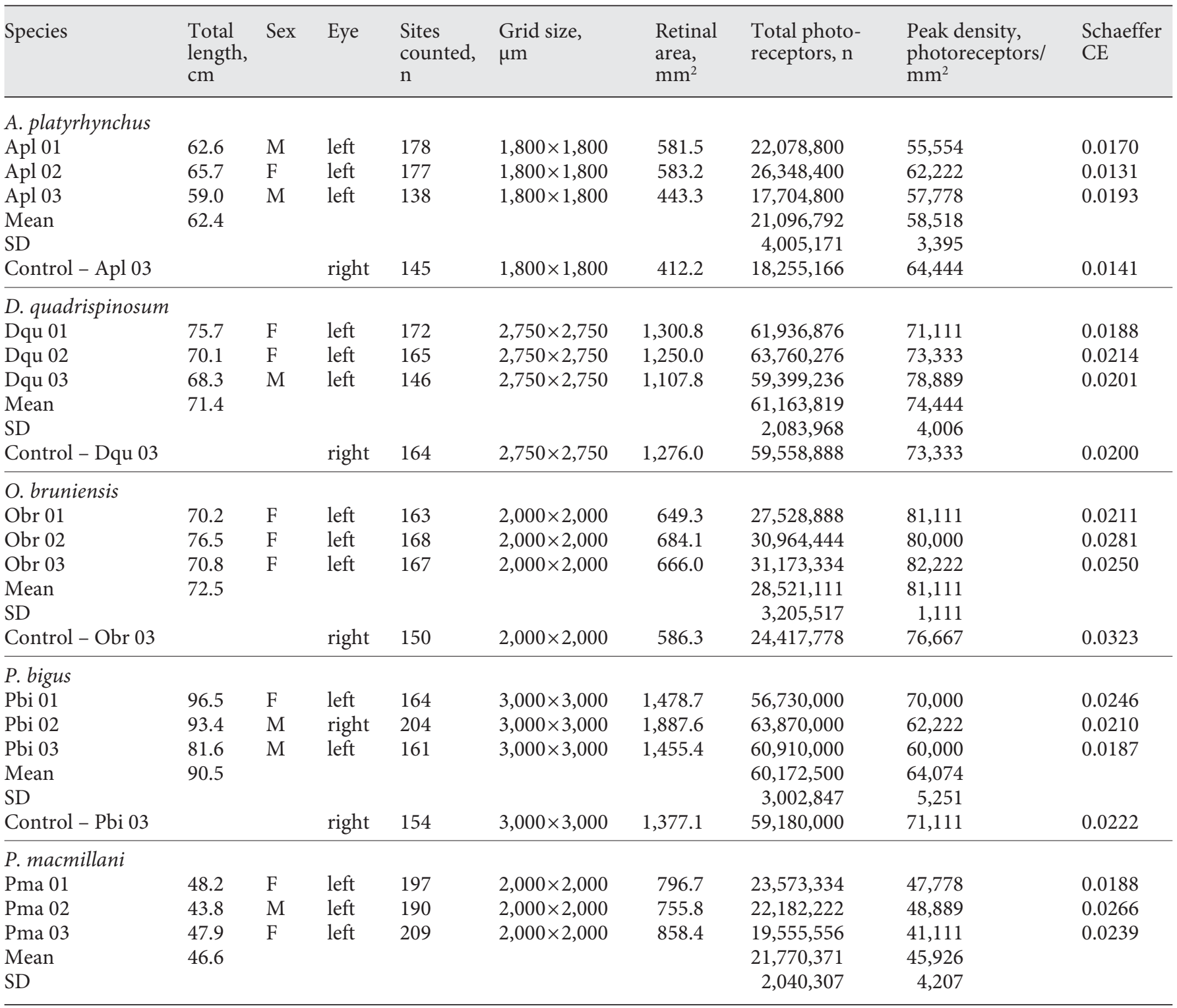

tapetum lucidum from the retinal pigment epithelium (RPE) that provides nutritional support for the photoreceptors. All 5 species possess only one morphological rod-like photoreceptor type characterized by their long cylindrical outer segments (fig. 4). The photoreceptor layer (PCL) consists of the long outer segments and shorter inner segments of the rod photoreceptors and contributes to around half of the retinal thickness. The rod inner segments are separated from their perikarya by a thin external limiting membrane (ELM). These photo- receptor perikarya form between 3 and 4 layers and lie in the outer nuclear layer (ONL). The inner nuclear layer (INL) is of similar thickness to the ONL and contains horizontal, bipolar and amacrine cells. Distributed regularly between the horizontal cells of the INL are Müller cells, which, like all non-neuronal glial cells, provide support for retinal neurons. The ganglion cell layer (GCL), unlike the previous cellular layers, is sparsely populated by both neuronal and non-neuronal cells. The innermost layer of the retina is the internal limiting membrane 
(ILM), which separates the retina from the vitreous humor.

Examination of transverse sections taken from different retinal regions revealed that in all species both retinal thickness and photoreceptor length are variable across the retina (fig. $4 c, d$ ). When viewed in a retinal wholemount, photoreceptors form a regular tightly packed hexagonal array, with the photoreceptor diameter also varying from one retinal region to another.

\section{Photoreceptor Number and Density}

The optical fractionator method revealed that both $A$. platyrhynchus and $P$. macmillani have the lowest total number of photoreceptors within the retina, with around $21,096,792 \pm 4,005,171$ and 21,770,371 $\pm 2,040,307$ cells, respectively (table 2 ). Interestingly, both species also rank the lowest in peak density of photoreceptors per square millimetre (A. platyrhynchus with a peak density of 58,515 $\pm 3,395 \mathrm{rods} / \mathrm{mm}^{2}$ within the areae compared to $P$. macmillani with a peak density of $45,926 \pm 4,207 \mathrm{rods} / \mathrm{mm}^{2}$ ). Both D. quadrispinosum and P. bigus show the highest total number of photoreceptors with around $61,163,819$ $\pm 2,083,968$ and $60,172,500 \pm 3,002,847$ rods, respectively. Although both species show a similar number of total photoreceptors within the retina, peak densities differ from $64,074 \pm 5,251 \mathrm{rods} / \mathrm{mm}^{2}$ in $P$. bigus to $74,444 \pm$ $4,006 \mathrm{rods} / \mathrm{mm}^{2}$ in D. quadrispinosum. Uniquely, O. bruniensis possesses a considerably lower total number of rods $(28,521,111 \pm 3,205,517)$ but has the highest peak density of all 5 species at $81,111 \pm 1,111 \mathrm{rods} / \mathrm{mm}^{2}$ (table 2).

Topographic Specializations within the Photoreceptor Layer

The analyses of the topographic variation in photoreceptor density in retinal wholemounts revealed that all species possess areas of specializations within the photoreceptor layer. The iso-density distribution maps show that all 5 species have some regional increases in photoreceptor density in both the temporal and the nasal regions of the retina, but the size, location of the specialization and density gradient vary considerably across the retina (fig. 5). In O. bruniensis, a clear increase in rod photoreceptor density exists across the retinal meridian, forming a weak horizontal streak with an area of high density $\left(81,111 \pm 1,111 \mathrm{rods} / \mathrm{mm}^{2}\right)$ in almost the centre of the retina (fig. 5e).

Both Parmaturus spp. (fig. 5b, c) show a strikingly similar arrangement of photoreceptor distribution with an increase in density across the horizontal meridian of the

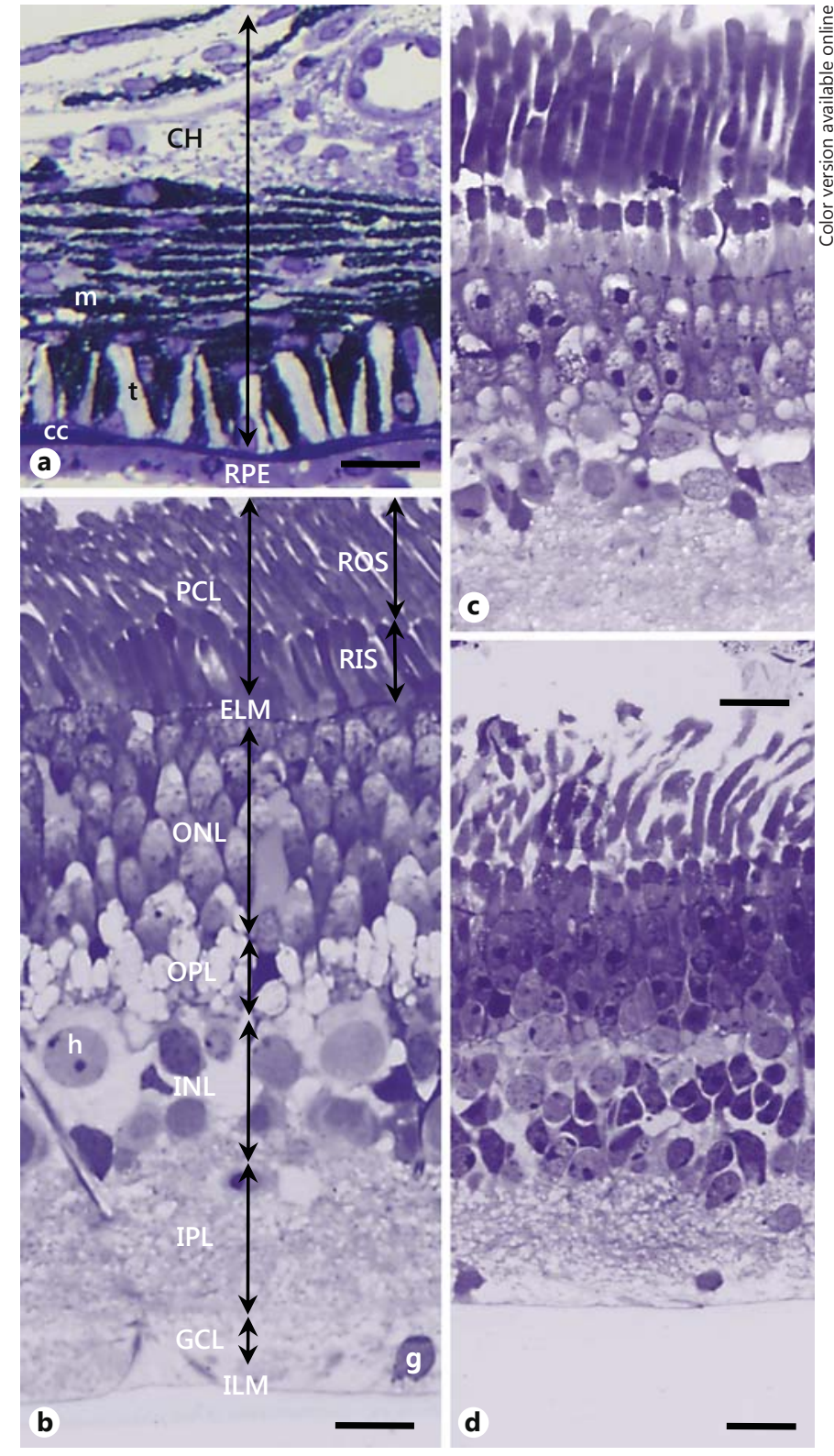

Fig. 4. Light micrographs of transverse sections of the deep-sea shark retina. a, b Retinal structure of the prickly dogfish, O. bruniensis. Note the position of the reflective tapetal cells ( $\mathrm{t}$ ) vitread to the choriocapillaris and the long slender rod outer cells that dominate the photoreceptor layer. $\mathrm{CH}=$ Choroid; $\mathrm{RPE}=$ retinal pigment epithelium; $\mathrm{PCL}=$ photoreceptor layer; ROS = rod outer segments; RIS = rod inner segments; ELM = external limiting membrane; $\mathrm{ONL}=$ outer nuclear layer; $\mathrm{OPL}=$ outer plexiform layer; $\mathrm{INL}=$ inner nuclear layer; IPL = inner plexiform layer; $\mathrm{GCL}=$ ganglion cell layer; ILM = inner limiting membrane; $\mathrm{m}=$ melanocyte; $c c=$ choriocapillaris; $\mathrm{h}=$ horizontal cell; $\mathrm{g}=$ ganglion cell . Retinal structure of the Borneo catshark, A. platyrhynchus, in the centro-dorsal region (c) and the periphery $(\mathbf{d})$. Note the change in rod photoreceptor length between the two sections. Scale bars $=20$ $\mu \mathrm{m}$. 


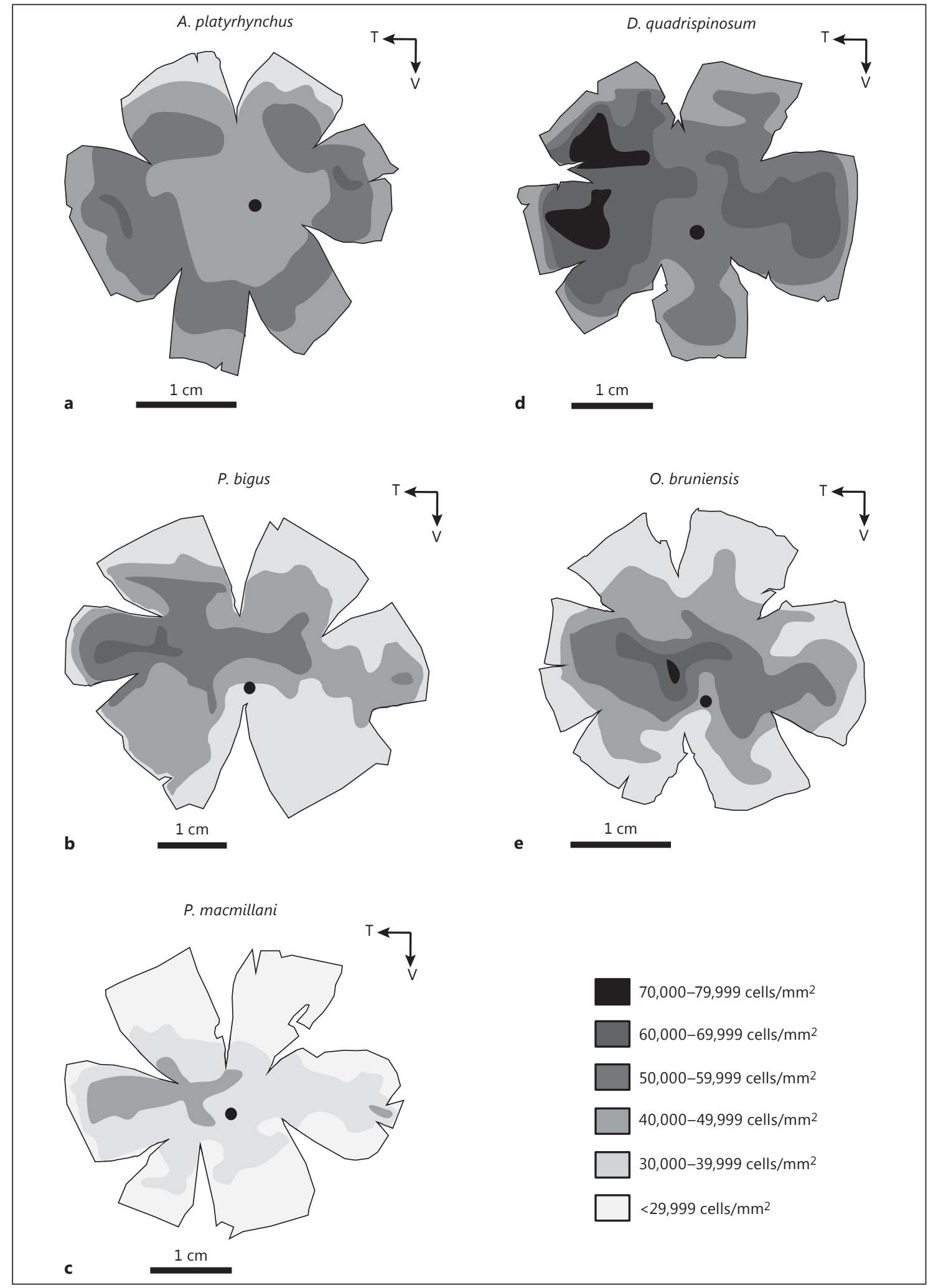

Fig. 5. Iso-density maps showing the topographic arrangement of rod photoreceptors of the 3 deep-sea catsharks from the family Scyliorhinidae, i.e. A. platyrhynchus (a), P. bigus (b) and P. macmillani (c), and the dogfishes from two families, i.e. Centrophoridae, D. quadrispinosum (d) and Oxynotidae, O. bruniensis (e). The black circle represents the position of the optic nerve head. $\mathrm{T}=\mathrm{Temporal} ; \mathrm{V}=\mathrm{ventral}$. 
retina, forming a very loosely defined visual streak. Furthermore, instead of a central area, as found in O. bruniensis, both species possess two regions of specialization with a small area in the nasal region (P. macmillani 40,370 $\pm 4,206 \mathrm{rods} / \mathrm{mm}^{2}$ and $P$. bigus $\left.54,444 \pm 6,939 \mathrm{rods} / \mathrm{mm}^{2}\right)$ and a larger area in the temporal retina ( $P$. macmillani $45,926 \pm 4,207$ rods $/ \mathrm{mm}^{2}$ and $P$. bigus $64,074 \pm 5,251$ rods $/ \mathrm{mm}^{2}$ ). Although these two closely related species have a similar topographic pattern of photoreceptor distribution, the range of densities differs significantly from 20,000 to 46,000 cells $/ \mathrm{mm}^{2}$ in $P$. macmillani to between 30,000 and 66,000 cells $/ \mathrm{mm}^{2}$ in P. bigus.

Both A. platyrhynchus and D. quadrispinosum lack a visual streak but show two unique arrangements of photoreceptor distribution (fig. 5a, d). D. quadrispinosum has a comparatively high density of photoreceptors across the whole retina (mean 50,837 $\pm 3,099$ rods $/ \mathrm{mm}^{2}$ ), reaching a peak in the extended temporal region $(74,444 \pm 4,006$ rods $/ \mathrm{mm}^{2}$ ), with a secondary increase in rod density $\left(64,074 \pm 5,481 \mathrm{rods} / \mathrm{mm}^{2}\right)$ located in the nasal retina. Likewise, A. platyrhynchus also reveals a reasonably uniform high density of cells across the entire retina (mean $41,275 \pm 4,097 \mathrm{rods} / \mathrm{mm}^{2}$ ), with a greater density towards the peripheral retina with small areae in both the temporal and the nasal regions (peaks of 58,515 $\pm 3,395$ and $57,037 \pm 3,572$ rods $/ \mathrm{mm}^{2}$, respectively). Interestingly, in A. platyrhynchus the lowest density of cells occurs in the dorsal retina.

\section{Discussion}

\section{The Eyes of Deep-Sea Selachians}

The lateral placement of the eyes in 4 of the 5 deep-sea species examined is commonly seen in many shark species irrespectively of the depth they inhabit, i.e. laterally placed eyes are found in both the shallow water whitetip reef shark, T. obesus [Litherland and Collin, 2008], and the shortspine spurdog, S. mitsukurii [Litherland et al., 2009]. Lateral eyes, with little or no binocular overlap, are perhaps necessary in species that spend much of their time continuously swimming in the water column, as the side-to-side sweep of the body would afford these species an extended surveillance of their horizontal visual field. An exception to this is A. platyrhynchus, which possesses a dorso-ventrally flattened snout resulting in almost a dorsal eye placement, a feature almost certainly associated with its assumed benthic lifestyle [Compagno et al., 2005]. Dorsally placed eyes are observed in other elasmobranch species, particularly skates and rays [Collin and
Pettigrew, 1988; Hart et al., 2004; Theiss et al., 2007] which are known bottom dwellers that prey predominantly on benthic invertebrates.

In contrast to shallower water sharks that often possess a pupil that can constrict to a slim ovoid, i.e. in the blue shark, Prionace glauca [Walls, 1942], and the blacktip reef shark, C. melanopterus [Kato, 1962], all 5 deep-sea shark species examined in this study possessed large, round, seemingly non-mobile pupils, although a more comprehensive study of pupil mobility in light-adapted and darkadapted light conditions is needed. To date, large fixed pupils have been reported in 3 other deep-sea species, i.e. the brown catshark, A. brunneus, the angular roughshark, O. centrina [Kuchnow, 1971], and the blackmouth catshark, G. melastromus [Bozzano et al., 2001], making it plausible that at least some, if not all, of the species in the present study may also possess fixed pupils.

A strong tapetal reflectance across the majority of the fundus was also exhibited by all 5 species. The presence of a tapetum is a characteristic reported in other shark species that inhabit considerable depths, including the green lanternshark, Etmopterus virens [Gilbert, 1963], and the shortspine spurdog, S. mitsukurii [Litherland et al., 2009]. Tapeta are also common among shark species from shallower waters, although coverage is often localized to specific parts of the fundus such as in the Port Jackson shark, Heterodontus portusjacksoni [Braekevelt, 1994]. A large, fixed pupil and strong reflective tapeta are two adaptations that deep-sea animals can employ to enhance sensitivity. Visual sensitivity is increased by increasing the number of photons that reach and are absorbed by the photoreceptors [Warrant, 2000; Warrant and Locket, 2004]. Both of these characteristics may be particularly useful in environments where bioluminescence may be the only source of light available [Lisney and Collin, 2007].

\section{Adaptations in Retinal Morphology}

A light microscopic examination of the retina in the 5 deep-sea shark species revealed an arrangement of cellular layers similar to that found in other elasmobranch species [Gruber, 1977; Kohbara et al., 1987; Hart et al., 2004, 2006; Litherland et al., 2009] and more broadly in other vertebrate species [Dowling, 1970]. One notable exception is that, when compared with terrestrial vertebrates, the photoreceptors in the adult elasmobranch retina constitute about half of the retinal thickness [Gruber, 1977]. Extending the length of the photoreceptors affords these species increased sensitivity without compromising spatial resolution through increased summation, 
which is another means of increasing visual sensitivity [Hart et al., 2006]. Examination of sections from across the retina in all species of the present study supports findings by Bozzano et al. [2001] that both photoreceptor length and hence retinal thickness are not consistent across the retina in deep-sea shark species, with increases occurring in regions of topographic retinal specialization.

All 5 species possess only one type of photoreceptor, morphologically similar to a rod and thereby providing scotopic vision and enhancing sensitivity under low light conditions. This finding is consistent with studies of 3 other deep-sea sharks examined for retinal morphology using light microscopy, i.e. the Portuguese dogfish, Centroscymnus coelolepis [Bozzano, 2004], the blackmouth dogfish, G. melastromus, and the spotted dogfish, Scyliorhinus canicula [Bozzano et al., 2001]. In addition to deep-sea sharks, some skate species have also been found to possess a pure rod retina [Dowling and Ripps, 1970; Szamier and Ripps, 1983]. However, as highlighted by Bozzano et al. [2001], it is important to remember that the presence of other photoreceptor types within the retina should not be completely ruled out, as they may be present in low numbers and/or may appear morphologically similar [Theiss et al., 2007]. Without specific photoreceptor markers, it is often difficult to definitively account for the complement of photoreceptor types as found by Sillman et al. [1996] who reported examining several hundred retinal micrographs of 2 benthic species of shark in order to locate 1 cone in the leopard shark, Triakis semifasciata, and 2 cones in the brown smooth hound, $M$. henlei.

\section{Implications of Photoreceptor Number and}

Topography on Feeding and Predator Avoidance

Due to the recent advances in retinal stereological procedures, coupled with the limited studies that have investigated photoreceptor cells within the retina of sharks (or even deep-sea vertebrates), this is the first study to employ stereology to map the topographic arrangement of photoreceptor cells within the photoreceptor layer of any selachian species. Furthermore, this is the first study to produce an estimate of the total number of photoreceptors present within the retina of elasmobranchs. This limits the potential to compare the total number and topographic arrangement of photoreceptors within the retina with other shark species. Further work on the visual system of deep-sea sharks using quantitative stereological techniques is required to gain a more complete understanding and a basis for ecological
Table 3. Comparative data of the estimated total number of photoreceptors found within the retina of 5 species using the retinal wholemount technique

\begin{tabular}{ll}
\hline Species & Total photoreceptors, $\mathrm{n}$ \\
\hline Human & $97 \times 10^{6 \mathrm{a}}$ \\
Rhesus monkey & $64 \times 10^{6 \mathrm{~b}}$ \\
Pigtail macaque & $63 \times 10^{6 \mathrm{c}}$ \\
Cebus monkey & $52 \times 10^{6 \mathrm{~d}}$ \\
Albino rat & $30 \times 10^{6 \mathrm{e}}$ \\
\hline
\end{tabular}

Data compiled from ${ }^{\text {a }}$ Curcio et al. [1990], b Wikler et al. [1990], ${ }^{c}$ Packer et al. [1989], d Andrade da Costa and Hokoç [2000], and ${ }^{\mathrm{e}}$ Mayhew and Astle [1997].

inference. However, to provide context for the number of photoreceptors present within the retina of the shark eye, photoreceptor populations of other vertebrate retinas investigated using the retinal wholemount technique are presented in table 3 .

Of the species of selachians studied to date, in this study and those using non-stereological methods, all species showed specializations of increased numbers of photoreceptor cells across the retina. The peak density of rod photoreceptors has been reported in 2 other deep-sea species, i.e. the Portuguese dogfish, C. coelolepis, at approximately 38,000 cells $/ \mathrm{mm}^{2}$ in the centro-temporal region of the retina [Bozzano, 2004] and in the shortspine spurdog, S. mitsukurii, at approximately 92,000 cells $/ \mathrm{mm}^{2}$ in the ventral retina [Litherland et al., 2009]. While a higher number of photoreceptor cells provides the animal with a greater sensitivity in a localized region of the retina, it is the identification of the corresponding part of the visual field that is mediated by this area that can provide an ecological context. An emerging pattern among the species of this study and C. coelolepis is that all species possess an increase in photoreceptor density in the temporal region of the retina. Due to the curvature of the eye, the temporal retina samples the nasal or frontal region of the visual field, and specializations in this area are almost certainly related to prey detection. Another common feature in the species examined in this study is a secondary increase or peak in photoreceptor density in the nasal retina. Although it has a lower peak density than the temporal specialization, this zone would afford these species with a higher sensitivity in the temporal or eccentric visual field and may alert these small species to predators approaching from behind. 
Interestingly, while the prickly dogfish, O. bruniensis, has some regional increase in photoreceptor density in the nasal retina, its most prominent area lies in the centro-temporal retina. This species is the only one to possess an area centralis and therefore may not rely on frontal fixation for the localization of prey. However, this central retinal zone mediating acute vision in the lateral visual space may alert this species to the approach of predators. This visual adaptation, in addition to the thickness and prickly condition of the skin due to the enlarged size of its dermal denticles, may be an important method of avoiding or deterring predators.

The placement of the eyes in the head of A. platyrhynchus gives an indication of its association with the benthos, and this is supported by its unusual topographic arrangement of photoreceptor cells. The dorsal orientation of the eyes limits downward vision, which would extend only as far as its pectoral margin. This means that, as in batoids [Sivak, 1976; Bozzano and Collin, 2000], vision may be of secondary importance for prey detection in this species and may be focused more on the detection of predators approaching from above, possibly without the need for excessive eye movements aiding concealment. The whitetip reef shark, T. obesus, displays a topography of photoreceptors [Litherland and Collin, 2008] that is somewhat similar to that of A. platyrhynchus, with an increased density of photoreceptors in the ventral half of the retina. T. obesus is known to be a semibenthic species, spending much of its time on or near the seafloor [Hobson, 1963]. This lends further support to the idea that $A$. platyrhynchus is closely associated with the benthos.

\section{Future Directions}

It is evident that increasing sensitivity of the retina is an important adaptation to life in the deep sea. As this study has illustrated, adaptations within the photoreceptor layer of the retina can increase sensitivity in specific parts of the visual field, and each species' visual demands may differ. However, it is the connections between photoreceptors, interneurons and, ultimately, the ganglion cells that dictate the spatial sensitivity/resolving power of an organism's visual system. Ganglion cells are responsible for transmitting incoming visual information to the visual centres of the brain, and the threshold at which these cells react to light stimuli is dependent on the number of photoreceptor cells to which they synapse [Schwartz, 2004]. As with all biological systems, there are a number of components that contribute to overall performance. The visual system is no exception and further research into the visual capabilities of deep-sea sharks should investigate these components, particularly on quantifying the visual input into the brain.

\section{Acknowledgments}

We would like to sincerely thank Joao P. Coimbra for his guidance and advice, especially for his expert assistance with stereology. The authors are also indebted to Anton's Seafood (New Zealand) for their kind and generous donation of specimens and sea time. Amy S. Newman was supported by an APAI from the Australian Research Council and a University of Western Australia postgraduate scholarship. This research was also supported by an ARC Discovery Grant to S.P.C. and ARC Linkage Grants to J.N.M. and S.P.C. The authors would also like to thank two anonymous reviewers for their comments on the manuscript.

\section{References}

Andrade da Costa BLS, Hokoç JN (2000): Photo- Arrese CA, Rodger J, Beazley LD, Shand J (2003): receptor topography of the retina in the new world monkey Cebus apella. Vision Res 40: 2395-2409.

-Arrese CA, Dunlop SA, Harman AM, Braekevelt CR, Ross WM, Shand J, Beazley LD (2000): Retinal structure and visual acuity in a polyprotodont marsupial, the fat-tailed dunnart (Sminthopsis crassicaudata). Brain Behav Evol 53:111-126.

- Arrese CA, Oddy AY, Runham PB, Hart NS, Shand J, Hunt DM, Beazley LD (2005): Cone topography and spectral sensitivity in two potentially trichromatic marsupials, the quokka (Setonix brachyurus) and quenda (Isoodon obesulus). Proc Biol Sci 272:791-796. Topographies of retinal cone photoreceptors in two Australian marsupials. Vis Neurosci 20:307-312.

Beaudet L, Flamarique IN, Hawryshyn CW (1997): Cone photoreceptor topography in the retina of sexually mature Pacific salmonid fishes. J Comp Neurol 383:49-59.

Bonthius DJ, McKim R, Koele L, Harb H, Karacay B, Mahoney J, Pantazis NJ (2004): Use of frozen sections to determine neuronal number in the murine hippocampus and neocortex using the optical dissector and optical fractionator. Brain Res Brain Res Protoc 14:4557.

-Bozzano A (2004): Retinal specialisations in the dogfish Centroscymnus coelolepis from the Mediterranean deep-sea. Sci Mar 68:185-195.
Bozzano A, Collin SP (2000): Retinal ganglion cell topography in elasmobranchs. Brain Behav Evol 55:191-208.

- Bozzano A, Murgia R, Vallerga S, Hirano J, Archer S (2001): The photoreceptor system in the retinae of two dogfishes, Scyliorhinus canicula and Galeus melastomus: possible relationship with depth distribution and predatory lifestyle. J Fish Biol 59:1258-1278.

Braekevelt CR (1986): Fine structure of the tapetum cellulosum of the grey seal (Halichoerus grypus). Acta Anat (Basel) 127:81-87.

Braekevelt CR (1994): Fine structure of the choroidal tapetum lucidum in the Port Jackson shark (Heterodontus phillipi). Anat Embryol (Berl) 190:591-596. 
Cavanagh R, Kyne PM (2005): The conservation status of deep-sea chondrichthyan fishes; in Shotton R (ed): Deep Sea 2003: Conference on the Governance and Management of DeepSea Fisheries. Rome, Food and Agriculture Organization of the United Nations, pp 366380.

Clarke GL, Denton EJ (1962): Light and Animal Life. New York, Interscience.

Clarke GL, Kelly MG (1965): Measurements of diurnal changes in bioluminescence from the sea surface to 2,000 meters using a new photometric device. Limnol Oceanogr 10:54-66.

Coimbra JP, Marceliano MLV, Andrade-da-Costa BLS, Yamada ES (2006): The retina of tyrant flycatchers: topographic organization of neuronal density and size in the ganglion cell layer of the great kiskadee, Pitangus sulphuratus and the rusty margined flycatcher, Myiozetetes cayanensis (Aves: Tyrannidae). Brain Behav Evol 68:15-25.

-Coimbra JP, Trévia N, Marceliano MLV, Andrade-da-Costa BLS (2009): Number and distribution of neurons in the retinal ganglion cell layer in relation to foraging behaviors of tyrant flycatchers. J Comp Neurol 514:66-73.

Collin SP (1988): The retina of the shovel-nosed ray, Rhinobatos batillum (Rhinobatidae): morphology and quantitative analysis of the ganglion, amarine and bipolar cell populations. Exp Biol 47:195-207.

Collin SP (2009): Early evolution of vertebrate photoreception: lessons from lampreys and lungfishes. Integr Zool 4:87-98.

Collin SP, Pettigrew JD (1988): Retinal topography in reef teleosts. 1. Some species with well-developed areae but poorly-developed streaks. Brain Behav Evol 31:269-282.

Compagno LJV, Dando M, Fowler S (2005): Sharks of the World. London, Harper Collins.

-Crescitelli F (1991): Adaptations of visual pigments to the photic environment of the deep sea. J Exp Zool Suppl 5:66-75.

-Curcio CA, Sloan KR, Kalina RE, Hendrickson AE (1990): Human photoreceptor topography. J Comp Neurol 292:497-523.

-Curcio CA, Sloan Jr KR, Packer O, Hendrickson AE, Kalina RE (1987): Distribution of cones in human and monkey retina: individual variability and radial asymmetry. Science 236 579-582.

Dowling JE (1970): Organization of vertebrate retinas: the Jonas M. Friedenwald Memorial Lecture. Invest Ophthalmol Vis Sci 9:655-680.

Dowling JE, Ripps H (1970): Visual adaptation in the retina of the skate. J Gen Physiol 56:491520 .

Fileta JB, Huang W, Kwon GP, Filippopoulos T, Ben Y, Dobberfuhl A, Grosskreutz CL (2008): Efficient estimation of retinal ganglion cell number: a stereological approach. J Neurosci Methods 170:1-8.

Finlay BL, Franco EC, Yamada ES, Crowley JC Parsons M, Muniz JA, Silveira LC (2008): Number and topography of cones, rods and optic nerve axons in new and old world primates. Vis Neurosci 25:289-299.
Fritsches KA, Marshall NJ, Warrant EJ (2003): Retinal specializations in the blue marlin: eyes designed for sensitivity to low light levels. Mar Freshw Res 54:333-341.

Gianni M (2004): High Seas Bottom Trawl Fisheries and Their Impacts on the Biodiversity of Vulnerable Deep-Sea Ecosystems: Options for International Action. Gland, IUCN.

Gilbert PW (1963): The visual apparatus of sharks; in Gilbert PW (ed): Sharks and Survival. Boston, Heath.

Glaser EM, Wilson PD (1998): The coefficient of error of optical fractionator population size estimates: a computer simulation comparing three estimators. J Microsc 192:163-171.

Gruber SH (1963): Cones in the retina of the lemon shark (Negaprion brevirostris). Vision Res 61:397-399.

Gruber SH (1977): The visual system of sharks: adaptations and capability. Am Zool 17:453469.

Gruber SH, Cohen JL (1985): Visual system of the white shark, Carcharodon carcharias, with emphasis on retinal structure. Mem Cal Acad Sci 9:61-72.

Gruber SH, Gulley RL, Brandon J (1975): Duplex retina in seven elasmobranch species. Bull Mar Sci 25:353-358.

Gundersen HJG, Jensen EB (1987): The efficiency of systematic sampling in stereology and its prediction. J Microsc 147:229-263.

Guthrie DM, Muntz WRA (1993): Role of vision in fish behaviour; in Pitcher TJ (ed): Behaviour of Teleost Fishes. London, Chapman \& Hall.

Hardy GS (1985): A new species of catshark in the genus Parmaturus Garman (Scyliorhinidae), from New Zealand. NZ J Zool 12:119-124.

Hart NS, Lisney TJ, Collin SP (2006): Visual communication in elasmobranchs; in Ladich $\mathrm{F}$, Collin SP, Moller P, Kapoor BG (eds): Communication in Fishes. Enfield, Science, pp 337-392.

-Hart NS, Lisney TJ, Marshall NJ, Collin SP (2004): Multiple cone visual pigments and the potential for trichromatic colour vision in two species of elasmobranch. J Exp Biol 207:4587-4594.

Hemmi JM, Gruenert U (1999): Distribution of photoreceptor types in the retina of a marsupial, the tammar wallaby (Macropus engenii) Vis Neurosci 16:291-302.

Hendrickson A, Djajadi HR, Nakamura L, Possin DE, Sajuthi D (2000): Nocturnal tarsier retina has both short and long/medium wavelength cones in an unusual topography. J Comp Neurol 424:718-730.

Hobson ES (1963): Feeding behaviour in three different species of sharks. Pac Sci 17:171194.

Hughes A (1977): The topography of vision in mammals of contrasting life style: comparative optics and retinal organization; in Crescitelli F (ed): Handbook of Sensory Physiology. Berlin, Springer, vol 7/5, pp 63-756.

Ivanoff A (1975): Introduction à l'Océanographie: Propriétés Physiques et Chimiques des Eaux de Mer. Paris, Vuibert.
Kato S (1962): Histology of the Retinas of the Pacific Sharks Carcharhinus melanopterus and Triaenodon obesus; MSc thesis, The University of Hawaii, Oahu.

Kohbara J, Niwa H, Oguri M (1987): Comparative light microscopic studies on the retina of some elasmobranch fishes. Nippon Suisan Gakk 53:2117-2125.

Kuchnow KP (1971): The elasmobranch pupillary response. Vision Res 11:1395-1406.

Last PR, White WT, Caira JN, Jensen K, Lim APK, Manjaji-Matsumoto BM, Naylor GJP, Pogonoski JJ, Stevens JD, Yearsley GK (2010): Sharks and Rays of Borneo. Melbourne, CSIRO.

Lisney TJ, Collin SP (2007): Relative eye size in elasmobranchs. Brain Behav Evol 69:266279

- Lisney TJ, Hawryshyn CW (2010): Ocular dimensions and cone photoreceptor topography in adult Nile tilapia Oreochromis niloticus. Environ Biol Fish 88:369-376.

Litherland L, Collin SP (2008): Comparative visual function in elasmobranchs: spatial arrangement and ecological correlates of photoreceptor and ganglion cell distributions. Vis Neurosci 25:549-561.

Litherland L, Collin SP, Fritsches KA (2009): Eye growth in sharks: ecological implications for changes in retinal topography and visual resolution. Vis Neurosci 26:397-409.

Lythgoe JN (1968): Visual pigments and visual range underwater. Vision Res 8:997-1012.

Lythgoe JN (1980): Vision in fishes: ecological adaptations. Environ Physiol Fish: 431-445.

Mayhew TM, Astle D (1997): Photoreceptor number and outer segment disk membrane surface area in the retina of the rat: stereological data for whole organ and average photoreceptor cell. J Neurocytol 26:53-61.

McCulloch AR (1915): Report on Some Fishes Obtained by the F.I.S. 'Endeavour' on the coasts of Queensland, New South Wales, Victoria, Tasmania, South and South Western Australia. 3. Zoological Results of the Fishing Experiments carried on by the F.I.S. 'Endeavour' 1909-14. Sydney, Direction of the Minister for Trade and Customs, pp 97-172.

McFarland WN (1986): Light in the sea: correlations with behaviors of fishes and invertebrates. Am Zool 26:389-401.

Ogilby JD (1893): Edible Fishes and Crustaceans of New South Wales. Sydney, Government Printer.

- Packer O, Hendrickson AE, Curcio CA (1989): Photoreceptor topography of the retina in the adult pigtail macaque (Macaca nemestrina). J Comp Neurol 288:165-183.

-Schieber NL, Collin SP, Hart NS (2012): Comparative retinal anatomy in four species of elasmobranch. J Morphol 273:423-440.

Schwartz SH (2004): Visual Perception: A Clinical Orientation, ed 2. New York, McGraw-Hill Medical.

Newman/Marshall/Collin 
Séret B, Last PM (2007): Four new species of deepwater catsharks of the genus Parmaturus (Carcharhiniformes: Scyliorhinidae) from New Caledonia, Indonesia and Australia. Zootaxa 1657:23-39.

Sillman AJ, Letsinger GA, Patel S, Loew ER, Klimley AP (1996): Visual pigments and photoreceptors in two species of shark, Triakis semifasciata and Mustelus henlei. J Exp Zool 276: $1-10$.

Sivak JG (1976): The accommodative significance of the ramp retina of the eye of the stingray. Vision Res 16:945-950.

-Slomianka L, West MJ (2005): Estimators of the precision of stereological estimates: an example based on the CA1 pyramidal cell layer of rats. Neuroscience 136:757-767.

Stell WK (1972): The structure and morphologic relations of rods and cones in the retina of the spiny dogfish, Squalus. Comp Biochem Physiol A Comp Physiol 42:141-151.

- Stell WK, Witkovsky P (1973): Retinal structure in the smooth dogfish, Mustelus canis: general description and light microscopy of giant ganglion cells. J Comp Neurol 148:1-31.
-Stevens JD, Bonfil R, Dulvy NK, Walker PA (2000): The effects of fishing on sharks, rays, and chimaeras (chondrichthyans), and the implications for marine ecosystems. ICES Mar Sci 57:476-494.

Stone J (1981): The Wholemount Handbook: A Guide to the Preparation and Analysis of Retinal Wholemounts. Sydney, Maitland Publications.

Szamier RB, Ripps H (1983): The visual cells of the skate retina: structure, histochemistry, and disc shedding properties. J Comp Neurol 215: $51-62$.

Tanaka S (1908): Notes on some Japanese fishes, with descriptions of fourteen new species. Coll Sci Tokyo Imp Univ 23:1-54.

Theiss SM, Lisney TJ, Collin SP, Hart NS (2007): Colour vision and visual ecology of the bluespotted maskray, Dasyatis kuhlii Müller \& Henle, 1814. J Comp Physiol A Neuroethol Sens Neural Behav Physiol 193:67-79.

Troilo D, Rowland HC, Judge SJ (1993): Visual optics and retinal cone topography in the common marmoset (Callithrix jacchus). Vision Res 33:1301-1310.
Walls GL (1942): The Vertebrate Eye and Its Adaptive Radiation. Bloomfield Hills, Mich., Cranbrook Institute of Science.

Warrant EJ (2000): The eyes of deep-sea fishes and the changing nature of visual scenes with depth. Philos Trans R Soc Lond B Biol Sci 355: 1155-1159.

Warrant EJ, Locket NA (2004): Vision in the deep sea. Biol Rev 79:671-712.

West MJ, Slomianka L, Gundersen HJG (1991): Unbiased stereological estimation of the total number of neurons in the subdivisions of the rat hippocampus using the optical fractionator. Anat Rec 231:482-497.

Wikler KC, Rakic P (1990): Distribution of photoreceptor subtypes in the retina of diurnal and nocturnal primates. J Neurosci 10:33903401.

Wikler KC, Williams RW, Rakic P (1990): Photoreceptor mosaic: number and distribution of rods and cones in the rhesus monkey retina. J Comp Neurol 297:499-508.

Wilder HD, Gruenert U, Lee BB, Martin PR (1996): Topography of ganglion cells and photoreceptors in the retina of a New World monkey: the marmoset Callithrix jacchus. Vis Neurosci 13:335-352. 